\title{
[Dis] Honesty of Taxpayers in the Self-Assessment System
}

\author{
Novrida Qudsi Lutfillah* \\ Jurusan Akuntansi \\ Politeknik Negeri Malang \\ Malang, Indonesia \\ *vridaoayu@gmail.com
}

\author{
Tri Agus Setiyawati \\ Jurusan Akuntansi, Fakultas Ekonomi dan Bisnis \\ Universitas Wijaya Putra \\ Surabaya, Indonesia
}

\begin{abstract}
This study aims to determine the practice of corporate taxpayer self-assessment system in terms of formal and material compliance. The type of qualitative research with an interpretive approach was chosen to understand the phenomena behind the practice of corporate taxpayer self-assessment system. The results showed that the corporate taxpayer in paying and reporting tax obligations is a form of formal taxpayer compliance that comes from rules and obligations. On the other hand, formal compliance does not always go hand in hand with honesty, especially in calculating taxes correctly and completely because corporate taxpayers are faced with the choice to be honest or dishonest.
\end{abstract}

Keywords: taxation, taxpayers, awareness, compliance

\section{INTRODUCTION}

the self-assessment system in tax collection in Indonesia that came into force in 1984 was the result of tax reform, which previously adopted the official assessment system [1]. The difference between the two systems lies in the responsibility in determining the tax. If the official assessment system in tax calculation is the responsibility of the tax authority, then in the self-assessment system the taxpayer is responsible for determining the tax and ensuring that the obligation is settled immediately [2]. The reason for changing the tax collection system to self-assessment system is as a form of respect for the rights as citizens whose citizens are equal to the state [3] and based on the government's trust in taxpayers because taxpayers know more about the benefits gained in their business activities [4].

Compliance of taxpayers in fulfilling voluntary tax obligations is the main capital in implementing the selfassessment system [5]. Forms of taxpayer compliance are formal and material. Formal compliance in the form of fulfilling tax obligations in accordance with applicable tax laws, while material compliance is related to the honesty of taxpayers in calculating and submitting tax reports in a complete, correct and timely manner [6]. Data from the Directorate General of Taxes of the Ministry of Finance until April 1, 2019 recorded the realization the annual notification letter (SPT) of individual and corporate taxpayers at $61.7 \%$ of the 18.3 million taxpayers who should report the SPT or a total of 11.3 million taxpayers who reports tax return. The amount is still far from the target set by the Directorate General of Taxes, reaching 15.5 million taxpayers or around $85 \%$ of the 18.3 million taxpayers who should SPT [7]. This condition shows the compliance of taxpayers in submitting SPT (formal) is still quite low and the condition still does not include material compliance, namely regarding the truth of the contents of the SPT.

The low compliance of taxpayers is influenced by various factors, such as awareness to meet tax obligations are still not optimal [8-10], the geographical location of an area that influences the SPT submission process because it takes a long time [11,12], lack of knowledge about tax [13], including understanding of the law and the concept of taxation $[14,15]$, lack of level of taxpayer trust in the government $[16,17]$ Chifamba argues that self-assessment cannot increase the level of compliance so there is a need for taxation socialization especially regarding electronic payment and tax reporting systems such as e-filling and e-billing which are still considered not easy, thus causing reluctance to report SPT $[12,18,19]$.

Previous research on taxpayer compliance has focused more on formal compliance, which is related to SPT reporting delivery factors. This study tries to develop the type of material compliance with corporate taxpayers, namely honesty of corporate taxpayers in reporting and calculating tax obligations correctly, completely and on time. In implementing the selfassessment system, corporate taxpayers are faced with two choices. The first option is to carry out the mandate given by the government to taxpayers, so that taxpayers respond with honesty in submitting income tax, the second allows corporate taxpayers to manipulate data on income earned, because the tax authorities do not interfere in the taxpayer's income tax calculation process. Based on this, this study aims to determine the practice of corporate taxpayer self-assessment system in terms of material compliance.

\section{METHOD}

Qualitative research was chosen in describing the practice of a corporate taxpayer self-assessment system, with an interpretive approach in understanding the phenomena behind 
"The maturity of PPH 21, PPH 23, Value Added Tax (VAT) and other types of taxes are different. at my place, the task of depositing the owner's responsibility, ... then the SSP proof is submitted to me for the need to report the SPT.

Makmur Company in carrying out the function of depositing taxes held directly by the owner. The limitation of the separation of this function is if the owner forgets to deposit taxes on time, which will hamper the reporting function. In practice, Makmur Company was once fined a penalty due to late payment of taxes.

In contrast to Nur, the tax staff of Maju Company, to avoid fines due to delays in the deposit function, the taxpayer has a dateline that falls before the due date besides there is good cooperation from the owner related to the deposit function as the following interview:

" My supervisor always checks up my duties, he always asks me about taxes to be paid, so the company is never subject to a fine ..."

Based on the practice of self-assessment system carried out by both taxpayers, it appears that the company has complied in fulfilling tax obligations in depositing and reporting tax returns. Punctuality in depositing and reporting both corporate taxpayers is done in order to avoid fines. This behavior can be said to be a form of compliance carried out by corporate taxpayers at the level of compulsion not because of selfawareness. Knowledge of taxation possessed by corporate taxpayers was apparently only used as a basis for certain actions rather than actual compliance.

\section{B. [Dis] Honesty the Practice of Self-Assessment System at the Level of Material Compliance}

The trust given by the tax authorities to corporate taxpayers to calculate, pay, and report is a form of trust. As in the Qur'an (4: $27 \& 58$ ) [22], Allah SWT commands humans to carry out the mandate (trust) that has been given to them. The mandate (trust) must be implemented properly and prohibited from betraying, such as the mandate given by the tax authorities to the corporate taxpayers to submit SPT correctly and honestly. The principle of honesty means being honest with self, fellow human beings and to God Almighty and is a basic principle as a form of devotion in carrying out all human affairs, one of which is in carrying out the State's command by paying taxes.

Maju Company and Makmur Company carries out his own counting function for VAT, while the corporate SPT is submitted to the Tania Tax Consultant appointed by the company where the informants work. The reason for the submission of the corporate SPT calculation to the tax consultant is not because of the informant's limited ability to carry out these responsibilities, as the reasons stated by Nur as follows:

"Actually I can calculate the company's tax, but because the company policy has been submitted to the consultant, so I joined the policy..".

Submitting a calculation to a consultant for Tina is a company policy that must be obeyed. For Tina there is an 
on the tax invoice, so the company bought the tax invoice from the supplier"

Tina explained that related to the purchase transaction, the tax invoice arrived at the process of repayment as follows:

"For example, if the bill is IDR150.000.000, - only 10\% will be paid. But in bank book transactions it is still worth IDR150.000.000. if asked how to process for 100\% money back, I do not understand because of the secret of the owner and supplier. What is clear is that the books must be in accordance with the company's purchasing procedures even though the actual transaction did not take place. "

In addition to VAT, Makmur Company also has a way to calculate Income Tax 21 as told by Tina:

"PPH 21 paid per month IDR230.000, - I don't understand how to calculate it, because the 1721 SPT was designed in a way that the company had 11 permanent employees, 1 manager and 1 leader. PPH 21 debts paid are always at this value."

When asked why the company calculates PPH 21 which is different from the real conditions, Tina herself does not understand the company's policy in calculating taxes as follows:

"I am not familiar with company policy and the reasons behind it, these methods may be part of corporate tax planning and beyond my knowledge because I focus on administrative implementation only."

\section{CONCLUSION}

The self-assessment system cannot be separated from trust and honesty. The tax authorities give trust to taxpayers to calculate their own amount of tax payable. With the trust that has been given by the tax authorities to the taxpayer, the taxpayer must act honestly in delivering the tax payable. Tax honesty is a measure of tax success. Without honesty, the meaning of self-assessment becomes useless. Although there is already a tax audit as a means of voluntary compliance in the self-assessment system, it does not mean that in practice honesty runs side by side with compliance. Honesty is related to the moral quality of taxpayers. Although there is now a phenomenon in society that breaking the law is not a disgrace, on the other hand there are still many moral people. Ideally, Ideally, honesty is created if there is self-awareness that tax evasion or fraud is a sin that will be sanctioned not only in the world but also in the hereafter.

\section{REFERENCES}

the underpaid position by crediting the input tax invoice, where the company does not buy the goods listed on the tax invoice as explained by Tina,

"So I received a tax invoice from the supplier, then an invoice planning was made by the accounting department. The invoice can be credited in the tax period needed to position the underpayment of the company's VAT. the invoice I received wasn't because of buying the goods listed
[1] Direktorat Jenderal Pajak, Undang-Undang Nomor 6 Tahun 1983 tentang Ketentuan Umum Dan Tata Cara Perpajakan (Lembaran Negara Republik Indonesia Tahun 1983 Nomor 49, Tambahan Lembaran Negara Republik Indonesia Nomor 3262), 1983.

[2] Direktorat Jenderal Pajak. Undang-Undang Nomor 16 Tahun 2009 tentang Ketentuan Umum Dan Tata Cara Perpajakan, 2009.

[3] H. Hasibuan, "Jangan takut diperiksa pajak, yuk kenali dulu sejarahnya," [online]. retrieved from http://www.medanbisnisdaily.com/news/online/, accesed on 25 Agustus 2019. 
[13] Waluyo, "Analisis pemahaman wajib pajak dan iklan otoritas pajak terhadap tingkat kepatuhan wajib pajak," Akuntabilitas, vol. VII, no. 3, pp. 177-184, 2014.

[14] T.W. Damayanti and Supramono "Apa Kata Mereka? Pengetahuan, Sikap, Niat Patuh Calon Pelaku Pajak," Akuntabilitas Jurnal Ilmiah Akuntansi, vol. 12, pp. 114-123, 2012.

[5] K.F. Choong and M.L Lai, "Self asesment taxs sistem and compliance complexity: tax practitioner perspectif,“ Oxford Buisiness and Economics Conference Program, 2009.

[6] S. Rahayu and I.T. Lingga, "Pengaruh modernisasi sistem administrasi perpajakan terhadap kepatuhan wajib pajak: survei atas wajib pajak badan pada KPP Pratama Bandung." Jurnal Akuntansi, vol. 1, no. 2, pp. 119-138, 2009.

[7] www.pajak.go.id

[8] E. Diamastuti, "Ke (tidak) patuhan wajib pajak: potret self assessment system,“"Ekuitas: Jurnal Ekonomi dan Keuangan, vol. 20, no. 3, pp. 280 $-304,2016$.

[9] C. Jotopurnomo and Y. Mangoting, "Pengaruh kesadaran wajib pajak, kualitas pelayanan fiskus, sanksi perpajakan, lingkungan wajib pajak berada terhadap kepatuhan wajib pajak orang pribadi di Surabaya," Tax \& Accounting Review, vol. 1, no. 1, pp. 49-54, 2013.

[10] C.D. Prihartanto and D. Pusposari, "Analisis faktor-faktor yang mempengaruhi kepatuhan wajib pajak dalam melakukan pembayaran pajak bumi dan bangunan perdesaan dan perkotaan (studi kasus pada wajib pajak PBB P2 Kecamatan Pesantren Kota Kediri)," Jurnal Ilmiah Mahasiswa FEB Universitas Brawijaya, vol. 2, no. 1, 2014.

[11] H.M.Y. Tita, "Implementasi mekanisme self assessment system pada daerah dengan latar belakang letak geografis wilayah kepulauan (studi perpajakan di Propinsi Maluku)," Perspektif Hukum, vol. 14, No. 2, pp. 137-144, 2014.

[12] E.E. Yusdita., I. Subekti and N. Adib "Peran persepsi wajib pajak atas keadilan sistem perpajakan dalam meningkatkan kepatuhan pajak," Ekuitas: Jurnal Ekonomi dan Keuangan, vol. 1, no. 3, pp. 361-384, 2017.

[15] N.H. Primasari, "Faktor-faktor yang mempengaruhi kepatuhan wajib pajak orang pribadi yang melakukan pekerjaan bebas.” Jurnal Akuntansi dan Keuangan, vol. 5, no. 2, pp. 180-199, 2016.

[16] S.W. Handayani, A. Faturokhman and U. Pratiwi, "Faktor-faktor yang mempengaruhi kemauan membayar pajak wajib pajak orang pribadi yang melakukan pekerjaan bebas," Simposium Nasional Akuntansi 15, Banjarmasin, 2012.

[17] A. Sugiono, U. Ludigdo and Z. Baridwan, "Makna pajak dan retribusi: perspektif wajib pajak pedagang kaki lima." Jurnal Akuntansi Multiparadigma, vol. 6, no. 1, pp. 53-78, 2015.

[18] C. Chifamba. The impact of Tax amnesty on compliance. Chinhoyi: Chinhoyi university, 2015.

[19] P.R.D. Ananda, S. Kumadji and A. Husaini, "Pengaruh sosialisasi perpajakan, tarif pajak, dan pemahaman perpajakan terhadap kepatuhan wajib pajak (studi pada UMKM yang terdaftar sebagai wajib pajak di Kantor Pelayanan Pajak Pratama Batu)," Jurnal Perpajakan (JEJAK), vol. 6, no. 2, pp. 1-9, 2015.

[20] L.J. Moloeng. Metodologi penelitian kualitatif. Bandung: Penerbit PT Remaja Rosda- Karya, 2007.

[21] Y. Mangoting and A. Sadjiarto, "Pengaruh Postur Motivasi terhadap Kepatuhan Wajib Pajak Orang Pribadi." Jurnal Akuntansi dan Keuangan, vol. 15, no. 2, pp. 106-116, 2013.

[22] Alqur'an 